ISSN: 2162-3104 Print/ ISSN: 2166-3750 Online

Volume 8, Issue 3 (2018), pp. 1108-1128

(C) Journal of International Students

http://jistudents.org/

doi: $10.5281 /$ zenodo. 1250413

\title{
Loving Neighbor as Self: Translating the Study Abroad Experience into Intercultural Friendships on the Home Campus
}

\author{
Kelly A. Pengelly \\ Taylor University, USA
}

\begin{abstract}
Universities focus significant attention on internationalization to prepare globally minded graduates by engaging students in study abroad programs and expanding international student enrollment. However, scholarship has not yet considered the role returned study abroad students play in meeting friendship needs of international students. This research aimed to determine if such experiences impact friendships between participants and internationals. Four basic themes emerged: isolated application of intercultural competencies, differences in empathy experiences, friendships between study abroad and international students, and institutional contributions. Key findings revealed institutions do not teach study abroad students to utilize their experience in fostering empathetic friendships with international students and should consider how the experience can more effectively impact intercultural friendships rather than focusing solely on domestic students' reverse culture shock.
\end{abstract}

Keywords: empathy, intercultural friendships, internationalization, international student, student development, study abroad

College and university students become exposed to unprecedented internationalization as institutions increasingly understand the saliency of preparing graduates for the global workforce. The Institute of International Education (IIE) opened its 2007 White Paper Report by stating, "To succeed 408 
and prosper in a global economy and interconnected world, U.S. students need international knowledge, intercultural communication skills, and global perspectives" (Obst, Bhandari, \& Witherell, 2007, p. 5).

Two desired outcomes for internationalization on campuses include intercultural competency and intercultural sensitivity. Intercultural competency refers to "the ability to think and act in interculturally appropriate ways" (Hammer, Bennett, \& Wiseman, 2003, p. 422). Intercultural sensitivity refers to "the ability to discriminate and experience relevant cultural differences" (Hammer et al., 2003, p. 422). Cross-cultural experiences prove crucial in developing these; thus, many schools embrace international student enrollment and the expansion of study abroad opportunities (ACE, 2012).

However, many scholars have expressed concern regarding the cultural divide existing on university campuses (Fischer, 2012; Gareis, 2012; Gudykunst, 1985; Memaj, 2012; Spring, 2003). The Director of International Students and Scholars at Michigan State University said that, despite university efforts made to minimize the divide, "there [was] still a lot of separateness" (Fischer, 2012, para. 23). Friendship-building seems difficult when international students face challenges in assimilation resulting from cultural differences, intercultural competence, personality, and identity (Gareis, 2012).

Research supports the need for more collaboration between international student programs and study abroad programs. However, little scholarship exists on how study abroad participants relate to international students upon their return, and this necessitates further study.

The present research aimed to determine if semester-long study abroad experiences impact friendships between study abroad participants and international students who study on the domestic campus and to identify factors that enhance or constrain students' development in this area. The term international student(s), for the purposes of the current study, referred to non-immigrant college students (excluding students with Canadian citizenship). Within the bounds of the study, the phrases friendship and meaningful friendships referred to intimacy that develops as an outgrowth of regular social contact.

\section{Perspective and Need for the Study}

This study targeted several key audiences. First, senior administrators set the tone for internationalization by creating strategies on 
campus (Mazon, 2010), while international student and study abroad directors implement key programs and initiatives. Second, student development professionals can help bridge gaps among campus departments by celebrating cultural differences "so that meaningful and numerous interactions occur between domestic and international students" (Mazon, 2010, p. 208).

Finally, professionals working directly in international student and study abroad programs perhaps hold the most influence on the interaction of these two student populations. Those in such positions need to not only collaborate but also understand the perceptions these students have towards friendships with each other. These professionals must mentor students in intercultural competencies.

The present study sought to answer the following key question: Does the study abroad experience equip participants with intercultural competencies that translate into meaningful friendships with international students on their home campus after the study abroad participants' return? The research also considered the following related questions:

- Does a semester-long study abroad experience result in improved intercultural competency and sensitivity as self-reported by the study abroad participants and as perceived by four year degree seeking international students?

- Does a semester-long study abroad experience result in increased levels of empathy among participants for the experience of international students on their home campus as self-reported by study abroad participants and as perceived by international students?

- Are study abroad participants using intercultural competencies to develop more meaningful friendships with international students on their home campuses?

- Is the institution contributing to the development of intercultural friendships between study abroad participants and international students? 


\section{LITERATURE REVIEW}

\section{Internationalization}

Researchers have attempted to define the internationalization phenomenon on U.S. campuses (ACE, 2012; Bennett, 2007; Deardorff, 2008; Kim, 2009; Spitzberg \& Changnon, 2009). Hudzik (2011) defined the key concepts as "a commitment, confirmed through action, to infuse international and comparative perspectives throughout the teaching, research, and service missions of higher education" (p. 1). Approximately $52 \%$ of collegiate institutions report the infusion of international perspectives into globally mindful outcomes as one of the "top five priorities in their strategic plan" (ACE, 2012, p. 7).

Due to changing student demographics, schools assess and alter methods (Altbach, Reisberg, \& Rumbley, 2009), making internationalization a greater focal point. Organizations like NAFSA believe internationalization endeavors "advance learning and scholarship, build understanding and respect among different peoples, and enhance constructive leadership in the global community" (NAFSA, 2013a).

\section{Individualistic vs. Collectivist Cultures}

Spring (2003) revealed the impact individualistic and collectivist cultures have on a student's education. Individualists typically include persons who prefer to work alone, care primarily for their own feelings, seem less prone to embarrassment, and think in categories. In general, collectivists work well in groups, attend to other's needs, are shy, seem less outspoken in class, and appear more likely to think about how things relate. Differences between these two cultural categories prove important in a predominantly individualistic U.S. culture that has not always done well in relationship with collectivist cultures (Spring, 2003).

\section{Empathy and Intercultural Sensitivity}

In addition to roadblocks caused by such cultural dissonance, research suggests a decline in student empathy, or "imaginatively taking on another person's thoughts and identifying with their emotions" (Anderson \& Konrath, 2011, para. 6). Konrath, O'Brien, \& Hsing (2011) showed that college students' standardized scores on an empathy test in the area of "perspective taking" dropped 34\% since 1980. Though certain cultural circumstances have led to the decline of empathy, researchers agree that 
ways must exist to impact it positively (Konrath et al., 2011). This goal can manifest in the context of internationalization with leadership from key administrators (Altbach et al., 2009; Hudzik, 2011; Mazon, 2010), who need to participate in conversations regarding internationalization as committees determine direction for generating intercultural sensitivity (Hammer et al., 2003).

Bennett's (1986, 1993) Development Model of Intercultural Sensitivity provides a framework for understanding stages from ethnocentrism (seeing one's culture as central to reality) to ethnorelativism, when one's "culture is experienced in the context of other cultures" (Hammer et al., 2003, p. 421). Study abroad programs and the presence of international students provide opportunities to exercise these intercultural sensitivities.

\section{Study Abroad}

The November 2017 Open Doors Report showed the number of domestic students studying abroad over the last 20 years has tripled (IIE, 2017). This increase does not automatically indicate effectiveness (Obst et al., 2007). Vande Berg, Connor-Linton, \& Paige (2009) found a significant number of study abroad students had not developed interculturally simply through exposure. The study abroad students who seemed to grow most had significant interaction with host nationals, engaged in national language acquisition, and had cultural mentors.

One criticism states that study abroad programs focus more on "consumer values" (Engle, 2013, p. 9), catering to the participants' interests to the detriment of desired learning outcomes. Institutions should encourage seeking understanding and embracing empathy in order to gain intercultural sensitivity and competency. Without someone encouraging and supporting these students, there exists the risk that newly gained competencies will disappear. Students need to know "how to learn, live, and communicate cross-culturally" (Montgomery \& Docter, 2010, p. 118-119) and to exercise new abilities by developing meaningful friendships with internationals on their home campus.

\section{Friendships with Internationals}

While most U.S. schools recognize the significance of trips abroad, they also give increased attention to the development of international student enrollment, as their numbers increased by $85 \%$ over the last decade 
(IIE, 2017). This surge comes with complexities. The average international student in the U.S. has grown up in a collectivist culture and now daily interfaces with a predominantly individualistic host culture.

Memaj (2012) noted, "40 percent of the international students said they have no close American friends" (para. 1). One of the study's participants from Honduras said, "Americans think ... they can't understand our cultures and ... they try to avoid us. Everyone gets scared they won't get the culture" (para. 5). International students come expecting to feel embraced by domestic students, learn English, and become immersed in the culture. Gareis (2012) pointed out that through meaningful friendships with domestic students internationals can acquire better language skills, which leads to academic success and less anxiety.

\section{Implications for English as a Second Language Learners}

The international student also studying English as a Second Language (ESL) may experience shyness and anxiety in social situations and may seem unwilling to participate in conversation (Liao, 2006). Some feel additional pressures from family to excel academically, focusing more on studies than on socializing (Liao, 2006). Friendships with nationals would help change the international student's perceptions.

Ultimately, internationalization should strive to give students knowledge and inspire a culture of curiosity. Schools "should think carefully about ... the types of opportunities the institution offers domestic and international students to interact in meaningful ways" (ACE, 2012, p. 19). The study abroad experience should not remain an isolated experience, demonstrating that with intercultural knowledge comes "responsibility for one's own neighborhood" (Postman, 1995, p. 100).

\section{RESEARCH METHOD}

This qualitative phenomenological case study utilized focus groups and individual interviews from a variety of populations. The qualitative approach proved effective in understanding the phenomenon of friendship development between returned study abroad participants and international students on their home campus. Through observation, listening, and inquiring, the researcher studied these relationships and gave both student groups opportunities to share their views while in the context of their own campus environment (Creswell, 2008). 
The empirical phenomenological design provided observable evidence through what Van Kaam (1966) described as the intended transaction between researcher and participant. The researcher "coexperience[d]" (p. 325) the perceptions, attitudes, and feelings of the participants in order to better understand their view of reality and give a better analysis of the data collected. Interviews explored the relational aspects through which study abroad participants and international students connected in friendship and understood each other despite cultural differences.

To refine the interview protocol, the researcher conducted a pilot study at a small, Midwestern, faith-based, liberal arts institution. The pilot study school had evaluated and restructured internationalization efforts. By conducting sample interviews with both study abroad participants and international students, the researcher obtained valuable feedback. This process indicated possible responses and themes by which the researcher could effectively modify the query (Creswell, 2008).

The researcher conducted interviews with individual administrators and student focus groups. The focus group approach allowed for dynamic group discussion (Harrell \& Bradley, 2009, p. 6) and multiple perspectives. Focus groups also responded to a brief survey. These multiple sources of insight provided evidence to explore, describe, and explain the sociological implications regarding friendships between these two groups (Yin, 1989).

\section{The Context}

The study took place at Fenley College (pseudonym), a mid-sized, Midwestern, private, faith-based, liberal arts college. According to the college website, $10 \%$ of the 4,000 students identify as international students. According to Open Doors, Fenley ranked nationally among leading baccalaureate institutions for the total number of students who engaged in study abroad programs and fifth highest among baccalaureate institutions for the total number of international students studying on the campus (Farrugia, Bhandari, Baer, Robles, \& Andrejko, 2017). The college also received NAFSA's Simon Award for exemplary work in the area of internationalization (NAFSA, 2013b).

\section{Individual, Administrative, and Focus Group Interview Participants}

First, the researcher conducted one-on-one interviews with key administrators to get a comprehensive perspective of the institution's 
process in developing a culture of international curiosity on campus. Those interviewed included the Assistant Dean of International Student Development, the Director of Off-Campus Programs, the Dean of Student Development, and the Provost. Next, the researcher interviewed two separate groups of five to seven students who spent at least one semester abroad. During the same campus visit, the researcher met with two separate groups of five to six international students. These students also had previous cross-cultural experiences before coming to Fenley.

Among the focus groups, some study abroad participants had visited countries home to international students on the campus. Likewise, in the international student focus groups, some representatives identified as being from the same countries that study abroad participants had experienced.

\section{Procedure}

All research participants received an explanation of the study and had opportunities to ask questions prior to signing a consent form. During the 30-45-minute recorded interviews, the researcher asked key administrators to share their perspectives regarding the strengths, weaknesses, opportunities, and threats of the internationalization process on their campus.

The researcher employed a semi-structured focus group method to create an informal ambiance in which study abroad student participants and international student participants felt comfortable. The researcher selected a casual setting for the focus group meetings and greeted the groups with refreshments to make them more at ease. Both focus groups first took a brief written questionnaire designed for the specific student populations of the research. The researcher then asked them to respond to discussion interview questions, using these questions and probes in order to cover all areas of interest. The focus group interviews lasted 60-90 minutes.

\section{Data Collection}

The researcher digitally recorded and transcribed individual and focus group interviews. Next, the researcher read through the interview transcripts, surveys, and any related documents collected, making note of initial impressions. The researcher analyzed data for significant statements and emerging themes, comparing perceptions shared by the different groups and compiling all major viewpoints. The researcher organized a table of significant statements of theme categories that arose, using the tables to 
create general qualitative descriptions. After these initial analytical steps, the researcher interpreted the information for meaning and validated it for accuracy (Creswell, 2008).

\section{RESULTS}

As a result of this qualitative study, the researcher uncovered significant perspectives related to friendships between study abroad participants and international students who study on the domestic campus. Four major themes emerged: isolated application of intercultural competencies, differences in empathy experiences with host nationals, friendships between study abroad and international students, and institutional contributions. The themes revealed untapped potential for intercultural friendship development that leads to enhanced intercultural competencies.

\section{Institutional Analysis}

To comprehend the state of internationalization, the researcher asked four Fenley administrators to reflect on strengths, weaknesses, opportunities, and threats encountered by study abroad and international student programs. Their commitment to global education was evidenced through clearly articulated and applied global values. Yet there remains work to meet financial and human resource challenges, to foster these values in the classroom, and to help domestics and internationals connect on an authentic human level. Campus-wide global initiatives include required cultural experiences, a residence floor focused on multicultural issues, and international students paired with nationals in an orientation class. Partnerships to promote intercultural competencies extend beyond student development offices into the classrooms, which also need much work. A Fenley administrator indicated that some faculty lack intercultural competencies. One even pointed out that some international students experience a certain level of social anxiety when interacting in the classroom:

We have this idea of international students coming into the class and sharing the values of the class. The professor may not understand where they are coming from. It can be difficult ... One student from Ghana was in a classroom and the professor 
kept on talking about Ghana and it was wrong ... [but] she just couldn't say anything to him.

When such incidents happen, the classroom becomes an uncomfortable place to learn.

In addition to classroom challenges, the impact of international enrollment and demands for more study abroad experiences make it difficult for departments to take full advantage intercultural experiences on campus or even with international alumni. Study abroad participants often engage in such programs for the wrong motives. One administrator commented that students often look for the exotic adventure, approaching study abroad trips as tourists. Also, a difficulty: study abroad participants and international students self-segregate and struggle to break out of their cultural friendship groups.

\section{Isolated Application of Intercultural Competencies}

The findings of the study revealed that semester-long study abroad experiences resulted in improved intercultural competency and sensitivity. However, improvement appeared isolated to the study abroad experience. Neither study abroad focus group could cite examples of leadership encouraging students to build on intercultural competencies by developing friendships with international students on campus.

One study abroad focus group participant shared: "When administration or group leaders talked [about our experience] it was always, 'Let's see, how can we help you get back to normal?'... I don't think that's right. I think it should be, 'How can you live differently now, how has this changed you?" Another student summarized: "I feel like most of the debriefing we received related more on how we could use it to relate to the students who hadn't left ... not necessarily how we would use it to relate to international students."

The study abroad focus groups agreed it felt easier communicating with internationals who came from destinations visited. A study abroad participant who visited Ghana stated, "[I]t definitely made it easier to relate to them and find common ground to get along." A Ghanaian student confirmed this, commenting, "It was nice having conversations and for once not trying to educate people on your culture."

A potential shortcoming surfaced, however, as the school sent students primarily to destinations not represented by the international student population. Both study abroad focus groups found it challenging to 
connect with internationals not from cultures they visited. One declared, "I would feel foolish saying or implying that [my study abroad trip] was a way that I could relate to them." One participant said she appreciated it when nationals in the study abroad host culture asked questions but expressed anxiety about talking to the international students on campus for fear of focusing too much on the fact that they come from a different country.

\section{Differences in Empathy Experiences}

The disconnect between intercultural knowledge gained while studying abroad and application of intercultural competencies became evident upon investigation. Study abroad focus groups shared repeatedly how they generally enjoyed interacting with host nationals; however, they could not identify personal testimonies indicating a desire to provide similar familial experiences of the U.S. culture for international students at Fenley College. They said building relationships with host nationals provided some of the most meaningful experiences in engaging culture. One study abroad participant shared how her Honduran family treated her like family: "We would talk about everything under the sun ... They had a genuine care for me. I ended up calling her mom and she called me daughter." Despite strong connections made with host nationals, students found it difficult to cultivate similar relationships with internationals on the campus at home.

The majority of international student focus group participants recalled friendly encounters with domestic students, being invited to join their group in the cafeteria or to study together. They mentioned that any time they left campus was with the help of domestic students. When the researcher asked both focus groups of international student participants if they had ever visited a domestic student's home, only one responded that he had visited the home of someone outside the Fenley community.

Study abroad focus group participants struggled to share ways in which they experienced and practiced empathy towards international students after they returned. However, one student shared: "I remember being in the library last fall and there was a group that was speaking in Korean. ... I thought to myself, 'Why can't you just talk English?' Then ... we got to Spain and I started speaking English. I thought to myself, 'I am so sorry, Korean-speaking students."”

When asked how they received empathy from domestic students, international student focus group participants shared examples such as being offered a place to stay during Christmas or receiving help with 
pronunciation. An international student described a domestic student's attempt to communicate empathy when her uncle in South Korea passed away. Her American friend tried to cheer her up with food instead of trying to talk to her. The international student shared, "I was not sure to be very sad about it. ... I wasn't sure how to feel [or] how to respond."

Miscommunicated empathy proved common. One administrator believed that international students struggle to interpret cultural cues, including well-meaning gestures of empathy. "I think generally this is a welcoming place where people are interested in others and 'Tell me your story.' The reason I say a slight 'no' is there can be a sense that the reason I am interested in you is because you are exotic." Despite dissonance between them, both study abroad and international student focus groups notably observed that study abroad participants who engaged in service-learning while overseas returned more empathetic and able to develop relationships with international students.

\section{Friendships between Study Abroad Participants and International Students}

While the findings of the study suggested that international students suffer from a lack of empathy from their peers, results also suggested that such empathy plays an important role in friendship development. Apparently, study abroad participants failed to exercise gained intercultural competencies to develop more meaningful friendships with international students on their home campuses.

When asked to describe relationships with domestic students, international student focus groups communicated genuine care and appreciation for others, especially those who demonstrated empathy toward them. However, they clearly considered themselves outsiders. One student said: "I never thought that making friends would be a problem. ... Cultural differences make it hard to connect with Americans." In fact, international students found it unusual when domestic students honored their word regarding friendships.

The majority of the international students came from collective cultures, with more relational and less time-oriented focuses, a distinction that required adjustment when they arrived. They complained that no one stays to find out the answer to the question, "How are you?" One student observed: "If an international and I are friends, we meet for the first time and then we go on from there and pick up where we left off. Americans are 
not like that. It is like you start from the beginning once, twice, three times but ... you never make headway." Another agreed: "You have a partner for a lab. You have a great discussion and you see them again ... and they just walk by. ... Back home, if you have a deep discussion you would be friends, and it's just frustrating because you thought you had a friendship."

International students said the campus proved extremely welcoming, but they struggled to move beyond what they considered shallow friendships. One administrator shared their perspective: "I think it is a $\sin$ of our culture. ... We are so busy and so task-oriented and timeoriented that we don't let people get close to us. ... I think it is a nice thing that internationals can teach us."

International students reported attempting to fit into a new culture by becoming a different person. They expressed how this adds to the complexity of the first-year experience of the international student. One international student's reflection captured this concept that all seemed to identify with: "Back home ... you have an identity and you feel safe in that. Then you come to college ... and people don't even know you. People are not really used to the way you interact with people at home so you have to 'tweak' your personality. ... When I came back the second year, it was easier to be my American self."

\section{Institutional Contributions}

Administrators felt unsure how to navigate complexities of intercultural competencies, empathy, and friendships between study abroad participants and international students. The interviews evidenced that, while the institution makes exceptional contributions, there remains a need to further develop intercultural competencies and friendships between these students. Through interactions with international students, domestic students learn to appreciate difference, to recognize their culture as not the norm, and to accept that all have "cultural ways." All administrators agreed on empathy as a desired outcome of the cultural exchange process. One administrator articulated, "It takes a person. ... Yes, it takes time and space and a person."

In short, the current research determined study abroad experiences minimally impact friendships between study abroad participants and international students who study on the domestic campus. The study identified key factors that enhance or constrain study abroad and international students' development in this area, as well as methods and 
factors that contribute to the formation of understanding, empathy development, and the creation of authentic friendships between domestic and international students at Fenley College. Based upon results from interviews and surveys, the following discussion addresses implications, limitations, future research, and suggestions for higher education practitioners, especially those responsible for student global mobility.

\section{IMPLICATIONS}

\section{Intercultural Disconnect}

Heightened intercultural competencies experienced in the study abroad destinations only translate into shallow friendships with international students on the home campus. Surveys indicate that a semester-long study abroad experience does improve study abroad participants' competencies, but development seems generally isolated to the study abroad experience. Study abroad participants apparently achieve ethnorelativity while abroad but slip back into ethnocentricity when they return (Bennett 1986, 1993). However, they appear to have a complete disconnect between skills they learn and experience while on their study abroad trip and external outcomes when they return. Study abroad participants either fail to understand how intercultural competencies can apply in building relationships on the home campus or they simply choose not to use them.

\section{Better Guests Than Hosts}

If what Twenge (2006) wrote proves true about today's narcissistic generation, this intercultural competency disconnect could result from students enjoying hospitality while in a foreign land but not necessarily thinking about how they might reciprocate in the exchange on the home campus. This study indicates domestic students may enjoy being on the receiving end of the intercultural exchange in a foreign land, but, due to their independent culture, they simply lack interest or motivation when presented opportunities to become the giver in the exchange on the home campus.

Empathy does not seem to flourish naturally in the campus cultural environment in the absence of training, dialogue, and mentoring, and without empathy, study abroad participants struggle to build such intercultural friendships. When students return from study abroad experiences, they should understand the concept of the global community 
and benefit to all members of the community if international students feel at home.

Hospitality to international students should also extend to the classroom. Some Fenley administrators agree there remains a need to educate professors in how to appropriately address cultural misunderstandings so they can model this desired hospitality toward internationals as they themselves grow in intercultural competencies.

\section{Perceived Institutional Values}

Colleges and universities may unknowingly send confusing messages when they promote the value of global engagement, as appears in many college and university mission statements. However, the value rarely reflects in international-domestic student relationships on campus. The study abroad experience aims to help students grow in intercultural competencies; however, students returning unchanged defeats a primary purpose. Schools should consider initiatives to change the direction of this phenomenon.

\section{Getting Back to Normal}

The students travel, engage with culture, but come back home the way they left. They return to the same friendships and unpack the experience with family. They also cease to exercise their newly developed intercultural competencies and sensitivities. As muscles atrophy without exercise, the same proves true with intercultural competencies. To better understand this phenomenon necessitates further study.

\section{LIMITATIONS AND FUTURE RESEARCH}

The study abroad focus groups lacked representation from first-time travelers. Many had returned less than a year before the present study, and a longer duration of return time would ensure participants sufficient time to exercise their intercultural competencies. A larger sample size from multiple campuses would add more depth of understanding.

International and domestic students likely have different motives for studying abroad. Perhaps study abroad students connected well in their destinations because people they met had no other means of encountering U.S. culture. The study did not explore how well international students connected with people at home. These unexamined factors may have influenced the study. 
The lack of study on this topic invites future studies on intercultural competencies, study abroad experiences, and relationships with international students on the home campus. A pre- and post-test and studying the impact of this phenomenon in public and private schools may contribute to knowledge of correlations between intercultural competencies, study abroad programs, and international students.

Additional research could also explore how service learning and faith-based programs influence intercultural competencies and domesticinternational student friendships. Institutions should analyze first-year study abroad programs to determine if greater impact appears. Study abroad programs that send students to the home countries of their international classmates and the American self trend, where international students adjust their personality to fit the host culture, merit further investigation. Some domestic students have never traveled abroad yet have a seemingly innate ability to relate to internationals. Research might reveal characteristics these students model. Finally, exploring how independent or collective cultures relate to internationalization initiatives on campus could prove beneficial.

\section{SUGGESTIONS FOR PRACTICE}

Results of the current study draw many helpful suggestions for practice. The study indicates a need to restructure the delivery of intercultural competencies through study abroad programs. The survival of humanity amid today's global issues requires both intercultural competence and 21stcentury skills (Deardorff, n.d.). Sustainable implementation depends on campus culture, stakeholder support, and finances. To eliminate the "isolated experience" of the study abroad trip, institutional cultures need to prepare students before they travel, giving them a context for building on friendships when they return.

\section{Timing of Study Abroad Programs}

Fenley College sends the majority of their students abroad during their junior year. Study abroad participants expressed concerns regarding the timing of their return and housing-related interactions. Based on this finding, institutions may consider the benefits of sending students earlier so they return to on-campus residential living with more time to exercise their intercultural competencies. 


\section{Making International Students Feel at Home}

Recognizing the opportunity to help domestic students develop diplomacy and hospitality, student development departments can collaborate in social activities to bridge domestic-international student relations. These departments can recruit returned study abroad students to make these events happen.

\section{First-Year Experience and Beyond}

In order to create campus cultures that foster intercultural friendships, institutions can require new students to study intercultural competencies during orientation and throughout their first year, providing mentorship and building intercultural opportunities into curriculum.

\section{Intercultural Competency Curriculum and Training for Faculty and Staff}

In order to further advance a culture of curiosity, schools could create an intercultural competencies certification program, earned through a series of workshops and activities. Faculty and staff should receive training in intercultural competencies, setting an example for the student population in their curriculum and through collegial friendships with ethnic and international coworkers. Special consideration should address the selection and training of faculty and staff who lead these trips. They should demonstrate gifts in mentoring and using their influence to inspire friendships among internationals.

\section{Strategic Collaboration Among Study Abroad, International Student, and Admissions Departments}

Study abroad directors could focus on developing programs in locations represented by the international student population. Enrollment management should consider strategies to engage prospective students where strong programs exist. The directors of international student and study abroad programs could pair students before study abroad participants leave, and the international students could share their experience in transitioning between cultures. Finally, these departments should provide ongoing social opportunities for these populations to intermingle. 


\section{Assessment}

Reflection and debriefing prove crucial to study abroad experiences. Institutions need to ensure that existing study abroad programs implement adequate time for contemplation. Some of Fenley's programs falsely advertised that study abroad participants would have national roommates or classes with nationals, opportunities that enrich the experience, but these never came to pass. Schools should investigate such practices, especially considering investments made by the school and students and the danger to desired outcomes.

Universities should consider pausing for a time of assessment to evaluate every study abroad program. Programs failing to meet institutional goals should be discontinued. They should also utilize pre- and post-test measurements of study abroad participants' growth in intercultural competencies, incorporating questions associated with domesticinternational student friendships. Learning outcomes should address how domestic students can give their international neighbors the benefit of the hospitality they received abroad rather than just "getting back to normal."

\section{Other Ideas}

Additionally, schools could provide more service learning trips that promote intercultural competencies, sensitivity, and empathy. Institutions of higher education could require student leader and study abroad participant references to respond questions regarding the applicant's ability to empathize with people from various racial and cultural backgrounds. Those responsible for debriefing need to point to the connections among students' growing intercultural competencies and encourage them to build relationships with international students. Finally, because "it takes a person," schools may need to prioritize finances to ensure adequate care of these important programs.

\section{CONCLUSION}

Schools like Fenley model great strides in the internationalization process. Still, evidence shows the need for greater collaboration to identify issues related to intercultural friendships on campuses. New structures need to bridge intercultural competency development both before and after study abroad experiences. By creating new initiatives that span four-year degree programs, schools demonstrate their seriousness in helping students 
incorporate intercultural competencies into everyday life, a habit that should extend beyond graduation. Institutions currently unsure how to accomplish this should take the time and resources to ensure sustainable results in order to deliver what they promise.

\section{REFERENCES}

Altbach, P. G., Reisberg, L., \& Rumbley, L. E. (2009). Trends in global higher education: Tracking an academic revolution. UNESCO World Conference on Higher Education. Retrieved from http://www.uis.unesco.org/ Library/Documents/trends-global-higher-education-2009-worldconference-en.pdf

American Council on Education (ACE), Center for International and Global Engagement. (2012). Mapping internationalization on U.S. campuses. Retrieved from http://www.acenet.edu/news-room/ DocumentsMappingInternationalizationonUSCampuses2012-full.pdf

Anderson, P., \& Konrath, S. (2011). Why should we care? What to do about declining student empathy. Chronicle of Higher Education. Retrieved from http://chronicle.com/article/Why-Should-We-Care-What/128420/

Bennett, J. M. (2007). Curiosity: The key to intercultural competence. Paper presented at the Families in Global Transition Conference, Houston, TX.

Bennett, M. J. (1993): Towards ethnorelativism: A developmental model of intercultural sensitivity. In R. M. Paige (Ed.), Education for the intercultural experience (2nd ed.; pp. 21-71). Yarmouth, ME: Intercultural Press.

Bennett, M. J. (1986). A developmental approach to training for intercultural sensitivity. International Journal of Intercultural Relations, 10, 179-196.

Creswell, J. W. (2008). Research design: Qualitative, quantitative, and mixed methods approaches (3rd ed.). Thousand Oaks, CA: Sage.

Deardorff, D. (2008). Intercultural competence: A definition, model and implications for education abroad. In V. Savicki (Ed.), Developing intercultural competence and transformation (pp. 297-321). Sterling, VA: Stylus.

Deardorff, D. (n.d.). Theory reflections: Intercultural competence framework/model. Retrieved from http://www.nafsa.org/_file/_/theory_ connections_intercultural_competence.pdf

Engle, L. (2013). What do we know now and where do we go from here? Keynote address presented at the Forum on Education Abroad, Chicago. Retrieved from http://apps.forumea.org/documents/LilliEngleKeynotewithslides.pdf

Farrugia, C., Bhandari, R., Baer, J., Robles, C. \& Andrejko N. (2017). Open Doors 2017 Report on International Educational Exchange. New York: Institute of International Education. 
Fischer, K. (2012). Many foreign students are friendless in the U.S., study finds. The Chronicle of Higher Education. Retrieved from http://chronicle.com/article/Many-Foreign-Students-Find/132275/

Gareis, E. (2012). Intercultural friendship: Effects of home and host region. Journal of International \& Intercultural Communication, 5, 309-328. doi:10.1080/17513057.2012.691525

Gudykunst, W. B. (1985). An exploratory comparison of close intracultural and intercultural friendships. Communication Quarterly, 33, 270-283.

Hammer, M. R., Bennett, M. J., \& Wiseman, R. (2003). Measuring intercultural sensitivity: The intercultural development inventory. International Journal of Intercultural Relations, 27, 421-443.

Harrell, M. C., \& Bradley, M. A. (2009). Data collection methods: Semi-structured interviews and focus groups. Rand National Defense Research Institute. Retrieved from http://www.rand.org/content/dam/rand/pubs/technical_ reports/2009/RAND_TR718.pdf

Hudzik, J. K. (2011). Comprehensive internationalization. Washington, DC: NAFSA, The Association of International Educators.

Institute of International Education (IIE), Open Doors. (2017). Executive summary. Retrieved from https://www.iie.org/Why-IIE/Announcements/2017-11-13Open-Doors-2017-Executive-Summary

Institute of International Education (IIE), Open Doors. (2012). International students: Leading institutions by institutional type. Retrieved from http://www.iie.org/Research-and-Publications/Open-Doors/Data/InternationalStudents/Leading-Institutions-By-Institutional-Type/2011-12

Kim, Y. Y. (2009). The identity factor in intercultural competence. In D. K. Deardorff (Ed.), The SAGE handbook of intercultural competence (2nd ed.; pp. 53-65). Thousand Oaks, CA: Sage.

Konrath, S. H., O'Brien, E. H., \& Hsing, C. (2011). Changes in dispositional empathy in American college students over time: A meta-analysis. Personality and Social Psychology Review, 15, 180-198.

Liao, C. T. (2006). The correlations between shy college EFL students in Taiwan and their English learning (unpublished doctoral dissertation). Pennsylvania State University, State College, Pennsylvania.

Mazon, B. K. (2010). Taking the global leap: Student affairs professionals and internationalization. Research in Comparative and International Education, 5, 205-209.

Memaj, E. (2012). Going beyond conversation partners: Helping international students make American friends. International Student Voice. Retrieved from http://www.isvmag.com/06/15/internationalmakingfriends/2098

Montgomery, L. M., \& Docter, M. (2010). With open eyes: Cultivating world Christians through intercultural awareness. In R. J. Morgan \& C. Toms Smedley (Eds.), Transformations at the edge of the world (pp. 117-131). Abilene, TX: Abilene Christian University Press. 
NAFSA: Association of International Educators. (2013a). Learn about NAFSA: Governing structure. Retrieved from http://www.nafsa.org/ Learn_About_NAFSA

NAFSA: Association of International Educators. (2013b). Simon award: Selection process. Retrieved from http://www.nafsa.org/Explore_International_Education/Impact/Awards/Se nator_Paul_Simon_Award/Simon_Award_Selection_Process

Obst, D., Bhandari, R., \& Witherell, S. (2007). Current trends in U.S. study abroad and the impact of strategic diversity initiatives. Institute of International Education. Retrieved from http://www.iie.org/Research-and-Publications/ Publications-and-Reports/IIE-Bookstore/Current-Trends-in-US-StudyAbroad-and-The-Impact-of-Strategic-Diversity-Initiatives

Postman, N. (1995). The end of education: Redefining the value of school. New York, NY: Knopf.

Spitzberg, B. H., \& Changnon, G. (2009). Conceptualizing intercultural competence. In D. K. Deardorff (Ed.), The SAGE handbook of intercultural competence (2nd ed.; pp. 2-52). Thousand Oaks, CA: Sage.

Spring, J. (2003). The intersection of cultures: Multicultural education in the United States and the global economy (4th ed.). New York, NY: Lawrence Erlbaum Associates.

Twenge, J. M. (2006). Generation me. New York, NY: Free Press.

Vande Berg, M., Connor-Linton, J., \& Paige, R. M. (2009). The Georgetown consortium project: Interventions for student learning abroad. Frontiers: The Interdisciplinary Journal of Study Abroad, 18, 1-75.

Van Kaam, A. (1996). Existential foundations of psychology. Pittsburgh, PA: Duquensne University Press.

Yin, R. K. (1989). Case study research: Design and methods. Newbury Park, CA: Sage.

KELLY A. PENGELLY, M.A., is the Director of International Student Programs and Services in the Office of Intercultural Programs, Taylor University. Her major research interests lie in the areas of intercultural development, international student issues, and empathy development. Email: kelly_pengelly@taylor.edu

Manuscript submitted: November 19, 2017

Manuscript revised: February 24, 2018 Accepted for publication: February 9, 2018 